\title{
GUARINELLO, NORBERTO LUIZ. HISTÓRIA ANTIGA. SÃO PAULO: CONTEXTO, 2013. $174 \mathrm{PP}$.
}

\author{
Rafael Augusto Nakayama Rufino ${ }^{1}$
}

The globalization process, discussed at length today, can be understood roughly as something that promotes the reduction of distances and the integration of people, without giving up the debates around its positive and negative aspects. But what is the reason for starting a book's presentation on the theme of Ancient History inserting a prior discussion of the characteristics of globalization? What would be the relationship between two seemingly disparate topics?

Ancient History comes to add on to this problematic. The author, Norberto Guarinello, is a Professor of Ancient History at the University of São Paulo (USP), and has dedicated his strength to the study of the ancient world questioning the central issue of the "history of the Mediterranean integration". According to the scholar, the historian is equipped with an instrument that consists of a time, a space and a question (or set of questions). The study of history would be fascinating due to the fact that when proposing new questions, one can look at the past in a radically new way. For this reason, "asking how a process of integration happens, in time and space, is a relevant issue." Thus, the integration of the Mediterranean in Antiquity is an issue that arises from the questions and reservations made on globalization in the contemporary world. After this thought, appears the question: would the space of the Mediterranean, with its integration process, have something to tell us today, to the problems faced today?

To carry out this task, Guarinello structured the book in nine chapters, and in each of them there are precise subdivisions that facilitate the understanding of the whole set. At the end of each chapter, the author pointed out some fundamental studies, in his view, to contribute with the debate.

\footnotetext{
${ }^{1}$ PhD student (History), CAPES Fellow. State University of Campinas - Campinas, SP, Brazil. e-mail: rafaelnakayama@hotmail.com
} 
A History of Ancient history is what moves and entitles the first chapter. It starts with the idea of the "creation of the ancient past", from the twelfth century, when there was still no discipline, but a sense of heritage, where the ancient texts represented something different from contemporary culture. Later on, Guarinello deals with the concept of the Renaissance, and criticizes the understanding of a reception as something from the past that arrives in the present in a whole, essential way: "It was not a passive reborn, but a deep reconstruction of memory with well marked goals". Finally, the disciplining of Ancient History would set between the seventeenth and eighteenth centuries, a period known as the Enlightenment. Some authors from this period are mentioned, such as Edward Gibbon, Georges Grote, Barthold Nierbuhr and Theodor Mommsen.

From the nineteenth century on, there is a new look towards the past and Ancient History receives inflows from the Social Sciences and Archaeology, emerging disciplines at the time, and new fields are opened for knowledge: the society, the family, the community, economy, culture and religion. In the late nineteenth century, with the rise of ideas like evolution, civilization, progress and European superiority on the rest of the world, Ancient History became the beginning of a progressive civilization line.

In the second chapter, Contemporary Ancient History, Guarinello thinks the process of reinterpretation of Ancient History, showing how the present motivations interfere in this writing and interpretation. They are: the two World Wars, the Russian Revolution, the revolution of the costumes in the 1960s and 1970s, the fall of the Berlin Wall and the end of communism and, more recently, globalization processes and its crises. It is important to note, in this regard, the changes brought to the discipline by the New Cultural History in the 1980s, when it promotes the category of identity, when it places Archaeology as important to the Ancient History studies, when it questions the discipline's chronological boundaries, among others. In short, using the author's own words, "the Ancient History was deconstructed".

Its thematic focus, the "Mediterranean studies", becomes explicit in the following chapter, The Mediterranean: integration process. Guarinello raises questions: how did the processes of human integration in the Mediterranean basin happen?; how was this progressive integration: what are its mechanisms, its causes, which are their periods of intensification and abatement". It is in this place, a world of small land areas, where different people have lived, isolated from each other but united by the sea.

Attempting to answer the questions above begins in chapter four, Navigations. Relying on the results of archaeological excavations he brings up the importance of the use of iron from the tenth century BC onwards, as well the Greek and Phoenicians sailors and navigations, to the process that promoted the contact between a wide range of local communities through the sea. Thus, the navigations propitiated cultural exchanges 
among different peoples. Moreover, from VIII, the Greek and Phoenician colonization starts, usually on the coast, in the occupation of territories for agricultural production.

Imbricated with the navigation discussion is the next chapter topic, City-States, for as Guarinello suggests, the city-state or polis "is a typically Mediterranean form of social organization, the result of the navigations age. [...] A social and political dominant organization of the communities along the Mediterranean in the following centuries. " An important consideration that is made is on the Polis as a phenomenon, not of all the Mediterranean peoples, but only the center ones. Egypt, the Far East and the Levant would not fit in this concept. The consequence of the Polis emergence was the reconfiguration of the Mediterranean integration processes. "The sea coast became more exclusive, more limited. The differences with the mainland territories began to stand out. Internal, local borders, and external, regional or Mediterranean, began to dialogue differently", Guarinello says.

The sixth chapter, Hegemonies, discusses the temporal range between V-II BC, knows as the "hegemonies period". This moment is marked by a large increase in social complexity in the Mediterranean, with the gradual emergence of big power centers in and over the Mediterranean, both Eastern and Western: the Persian Empire (Levant, Phoenician cities, Egypt, the kingdom of Lydia), Athens, Sparta, Macedonia, Carthage, Syracuse, Tarentum, Rome, who waged countless conflicts with each other, causing the reconfiguration of Mediterranean borders. It is precisely one of them, Rome, which went on to expand its hegemony, initially in the Italian peninsula, along with its allies. There was, in this sense, an innovation of the integration structures, such as roads' construction, uniting, slowly, all of Italy centers. The expansion of Latin was also part of that process. It is not too much to say, as Guarinello considers, that this expansion was not without conflict, even less without the formation of a broad alliance with other cities.

The two following chapters are devoted to the Roman Imperialism and the Empire, the latter from Augustus' government on. With the Roman expansion in the Italian peninsula, as well as the end of the war against the Carthaginians (III BC), two other fronts have become targets: the north of the Mediterranean and the Iberian Peninsula; and the Eastern Mediterranean. With the achievements came the influx of wealth, the use of slave labor and, paradoxically, the appearance of cracks in the imperial center itself, which led to a civil war in the second century BC. Its origins can be traced by the lack of wealth distribution and the rebellion of their own allies for a greater share in the spoils of war. Therefore, Guarinello notes that the civil war in Rome can be seen as a "world war", an understanding that becomes possible because of the Mediterranean integration: "Only the slow process of accumulation of connections, interconnections, networks and interconnected structures explains how the fight within a city could, 
simultaneously, be a Mediterranean war". As for the imperial order that would have started with Augustus, Guarinello is categorical: "The Roman Empire, which lasted for centuries, was only possible under the basis of centuries of integration and consolidation of structures that preceded it". Even the spread of Christianism was possible largely due to the Mediterranean communication networks.

Finally, the issue of Late Antiquity is discussed in the last chapter. This concept, which gained academic status since the publication of the book The World of Late Antiquity $(1971)^{2}$, by the American Peter Brown, refers to a much broader and fluid period (IIVIII AD), that, to Guarinello, was "a time of great changes, starting with a radical state reform and its relations with society". A central contribution that this concept brought was the critique of the idea of "barbarian invasions", which, contrary to what was argued, was a "process of integration wider and less destructive, according to which the imperial power did not fall, but reorganized itself into smaller and interdependent political units". Thus, there is a tendency to perceive more continuities than discontinuities in these centuries.

Having said that, what the reader has at hand is an introductory work on Ancient History, written by one of the greatest Brazilian experts. The cutout is clear and evident from the start, which is commendable because it demonstrates the distancing of the author from an apodictic discourse, to be remembered on several occasions about the importance of "arbitrariness with conscience".

Other points deserve further comment: the importance the author gives to information from archaeological sources, essential, in many cases, for the study period; as the outline is the Mediterranean, the author is not limited to the study of Antiquity as a synonym of Greece and Rome, commonly stamped in Ancient History courses in most Brazilian universities, and expands his analysis to all the peoples of the western and eastern Mediterranean; when comes the Roman imperialism, the author moves away from a normative interpretation, in which Rome would have imposed their culture or where there would have been an acceptance of the subjected peoples of their supposed civilizing mission, and points to the conflicted, unstable character in relation to the imperial order.

${ }^{2}$ BROWN, Peter (1971) The World of Late Antiquity: From Marcus Aurelius to Muhammad. London (2nd ed. expanded:. The World of Late Antiquity 150-750 AD New York, 1989). 
Guarinello's work has many qualities for what it is intended: to be an introductory and dissemination piece on the field of Ancient History. However, at times, a more straight explanation of the historiographical debates that are being put by the author, the ones that move assumptions or findings, are missing, and those clarify a good deal to the more interested reader. Maybe they were not irreconcilable issues in the context of the work.

Still, this is just a detail that does not dazzle its quality, which has the great merit of taking Ancient History out of its ivory tower, as something unshaken in the face of worldly problems, a holy place for the positivist and conservative cult, to show how it is linked to current desires. After all, "the Mediterranean world does not give us accurate answers, but poses questions that are contemporary and very important," Guarinello concludes. 